\title{
Antihiotik Terapi Demam Tifoid Tanpa Komplikasi pada Anak
}

\author{
Novie Homenta Rampengan \\ Bagian Ilmu Kesehatan Anak, Fakultas Kedokteran Universitas Sam Ratulangi/RSU Prof.Dr.R.D. Kandou, \\ Manado
}

Latar belakang. Demam tifoid masih merupakan masalah kesehatan khususnya di Indonesia. Kloramfenikol merupakan obat pilihan lini pertama untuk terapi demam tifoid tanpa komplikasi pada anak sampai saat ini. Antibiotik lain yang dipergunakan adalah tiamfenikol, sefiksim dan azitromisin.

Tujuan. Melakukan evaluasi respon antibiotik yang digunakan dalam terapi demam tifoid tanpa komplikasi di Bagian Ilmu Kesehatan Anak RSU Prof.Dr.R.D.Kandou, Manado.

Metode. Penelitian kohort retrospektif dilakukan di Bagian Ilmu Kesehatan Anak RSU Prof.Dr.R.D.Kandou, Manado, Juli 2007-Juni 2012 pada anak usia 6 bulan-13 tahun dengan diagnosis demam tifoid. Data diperoleh dari rekam medik pasien. Waktu bebas demam dan lama rawat pada tiap kelompok antibiotik di data. Analisis statistik dilakukan dengan menggunakan ANOVA dengan uji F dengan program SPSS 17.

Hasil. Didapatkan 161 kasus yang memenuhi kriteria inklusi. Antibiotik terbanyak dipakai adalah kloramfenikol (31,1\%), tiamfenikol (27,3\%), sefiksim (23\%), dan azitromisin (18,6\%). Waktu bebas demam paling pendek dicapai pada kasus yang diberikan azitromisin yaitu 37,9 (SB 32,8) jam, diikuti oleh kloramfenikol 40,3 (SB 28,3), tiamfenikol 45,3 (SB 38,1) dan sefiksim 50,8 (SB 32,3). Rerata lama rawat paling cepat ditemukan pada kelompok kloramfenikol yaitu 4,4 (SB 1,3) hari, diikuti dengan azitromisin 4,6 (SB 1,3), tiamfenikol 4,8 (SB 1,7) dan sefiksim 4,8 (SB 1,6) Tidak terdapat perbedaan bermakna rerata waktu bebas demam dan lama rawat keempat jenis antibiotik.

Kesimpulan. Pemberian antibiotik kloramfenikol, tiamfenikol, sefiksim, dan azitromisin pada demam tifoid anak tidak terdapat perbedaan bermakna pada rerata waktu bebas demam dan lama rawat inap.

Sari Pediatri 2013;14(5):271-6.

Kata kunci: demam tifoid, antibiotik, waktu bebas demam, lama rawat inap

Alamat korespondensi:

Dr. Novie Homenta Rampengan, Sp.A. Bagian Ilmu Kesehatan Anak FK UNSRAT/RSUP Prof. R.D. Kandou Manado. Jl. Raya Tanawangko, Manado 95263, Telp. 62-431-821652, Fax. 62-431-859091. E-mail: novierampengan@yahoo.com
$\mathrm{P}$ enyakit demam tifoid masih merupakan masalah kesehatan khususnya di Indonesia dan negara berkembang lainnya. Insidens demam tifoid masih tinggi meskipun komplikasi dan angka kematian sudah menurun dengan upaya diagnosis cepat dan pemberian antibiotik yang tepat. 
Dari telaah kasus di beberapa rumah sakit besar, kasus tersangka demam tifoid menunjukkan kecenderungan yang meningkat dari tahun ke tahun dengan rata-rata kesakitan 500/100.000 penduduk dengan kematian antara $0,6 \%-5,0 \% .^{1}$

Obat-obat lini pertama dalam pengobatan demam tifoid adalah kloramfenikol, tiamfenikol atau ampisilin/amoksisilin. Kloramfenikol masih merupakan pilihan utama untuk pengobatan demam tifoid karena efektif, murah, mudah didapat, dan dapat diberikan secara oral. Umumnya perbaikan klinis sudah tampak dalam waktu 72 jam dan suhu akan kembali normal dalam waktu 3-6 hari, dengan lama pengobatan antara 7-14 hari. ${ }^{2,3}$ Namun demikian, dalam lima tahun terakhir telah dilaporkan kasus demam tifoid berat pada anak bahkan fatal yang disebabkan oleh adanya resistensi obat ganda terhadap Salmonella typhi (multiple drugs resistance $(M D R))$. Disamping itu pemakaian kloramfenikol dapat menimbulkan efek samping berupa penekanan sumsum tulang dan yang paling ditakuti terjadinya anemia aplastik. Sefalosporin generasi III (seftriakson, sefotaksim, sefiksim), fluorokuinolon (siprofloksasin, ofloksasin, perfloksasin) dan azitromisin saat ini sering digunakan untuk mengobati demam tifoid MDR. ${ }^{4-6}$

Penelitian kami bertujuan untuk mengevaluasi respon antibiotik yang digunakan dalam terapi demam tifoid tanpa komplikasi di ruang Rawat Inap Anak, Bagian Ilmu Kesehatan Anak RSU Prof. Dr.R.D.Kandou, Manado.

\section{Metode}

Penelitian dengan desain kohort retrospektif terhadap pemakaian antibiotik untuk demam tifoid anak dilakukan dengan analisis catatan rekam medik pasien demam tifoid yang dirawat di ruang rawat inap anak bagian IKA FK UNSRAT / RSU Prof.Dr.R.D.Kandou, Manado, selama 5 tahun, yaitu sejak bulan Juli 2007 - Juni 2012. Kriteria inklusi ialah 1) semua pasien berusia 6 bulan - 13 tahun dengan catatan medik lengkap, terdiagnosis demam tifoid tanpa komplikasi, 2) tidak terdapat riwayat hipersensitifitas terhadap antibiotik, 3) tidak menderita penyakit penyerta atau infeksi lain misalnya gizi buruk, tuberkulosis, infeksi saluran kemih, demam berdarah dengue, atau campak. Semua pasien yang mendapat obat antibiotik injeksi, antibiotik kombinasi, meninggal atau pulang paksa dari rumah sakit tidak diikutsertakan dalam penelitian. Diagnosis demam tifoid ditegakkan berdasarkan riwayat demam 7 hari atau lebih dengan minimal satu dari gejala/tanda terkait tifoid (diare, mual/muntah, nyeri perut, anoreksia, konstipasi, perut kembung, lidah kotor, hepatomegali, atau splenomegali) dan laboratorium berupa tes tubex $\geq 4$ atau titer widal Salmonella typhi $O \geq 1 / 320$, tanpa disertai dengan kesadaran menurun, kejang, perdarahan usus berupa melena atau perforasi usus, syok atau koma.

Data rekam medis ditelusuri untuk diambil data demografi (usia dan jenis kelamin) dan gejala klinis, laboratoris, jenis terapi serta respon terapi berupa waktu bebas panas, dan lama perawatan di rumah sakit. Waktu bebas panas adalah waktu dalam jam, dari pemberian obat sampai suhu badan turun kurang dari $37,5^{\circ} \mathrm{C}$ dan bertahan paling kurang 48 jam. Lama pemberian antibiotik pada semua kelompok antibiotik adalah 7 hari. Data pengobatan didapat dari rekam medik, direkam pada formulir profil pengobatan yang telah didesain terlebih dahulu agar memudahkan peneliti pada saat mengevaluasi. Semua data kemudian direkam dalam format microsoft office excell dan dianalisis. Data demografi dianalisis dengan deskriptif analisis. Perbandingan waktu bebas panas dan lama rawat rumah sakit pada tiap kelompok antibiotik dianalisis dengan ANOVA uji $\mathrm{F}$ menggunakan program SPSS versi 17.

\section{Hasil}

Analisis terhadap rekam medis menemukan 161 pasien demam tifoid yang memenuhi kriteria inklusi. Dari 161 pasien, 94 diberikan lini pertama dalam terapi demam tifoid tanpa komplikasi, yaitu 50 (31,05\%), menerima terapi kloramfenikol (dosis $100 \mathrm{mg} / \mathrm{kg} /$ hari), dan $44(27,33 \%)$ menerima tiamfenikol (dosis $75 \mathrm{mg} / \mathrm{kg} / \mathrm{hari}$ ). Terapi lini kedua, yaitu sefiksim (dosis $10 \mathrm{mg} / \mathrm{kg} / \mathrm{hari})$ diberikan pada 37 (22,98\%) pasien dan azitromisin (dosis $10 \mathrm{mg} / \mathrm{kg} /$ hari) diberikan pada $30(18,64 \%)$. Lama pemberian antibiotik pada semua kelompok antibiotik adalah 7 hari.

Tabel 1 memperlihatkan insidens demam tifoid pada laki-laki dan perempuan hampir sama. Rerata usia pasien demam tifoid terbanyak di atas 5 tahun. Lama demam sebelum masuk rumah sakit berkisar antara 8-8,6 hari. Rerata suhu tubuh saat masuk rumah 
sakit antara $37,6^{\circ} \mathrm{C}-38,1^{\circ} \mathrm{C}$. Sebagian besar pasien telah mendapatkan pengobatan sebelum masuk rumah sakit. Tabel 2 memperlihatkan gejala klinis terbanyak diderita adalah anoreksia, mual dan muntah, nyeri perut, serta batuk. Tabel 3 memperlihatkan rerata hasil laboratorium darah rutin yang berada dalam batas normal. Tabel 4 memperlihatkan respons terapi berbagai antibiotik yang digunakan dalam penelitian kami, yang dinilai dengan waktu bebas panas, dan lama rawat di rumah sakit. Waktu bebas panas paling pendek dicapai pada pasien yang diberikan azitromisin yaitu 37,9 (SB 32,75) jam, kemudian diikuti oleh kloramfenikol yaitu 40,3 (SB 28,3), tiamfenikol 45,27 (SB 38,05), dan sefiksim 50,81 (SB 32,3). Hasil Anova dengan uji $\mathrm{F}$ menyatakan tidak terdapat perbedaan bermakna rerata waktu bebas panas ke- 4 jenis obat $(\mathrm{p}=0,348)$.

Tabel 5 memperlihatkan rerata lama rawat paling singkat ditemukan pada kelompok kloramfenikol, yaitu 4,42 (SB 1,26) hari, disusul oleh kelompok

Tabel 1. Karakteristik umum subyek penelitian

\begin{tabular}{lcccc}
\hline Karakteristik & Kloramfenikol & Tiamfenikol & Sefiksim & Azitromisin \\
\hline Jumlah, $\mathrm{n}(\%)$ & $50(31,05)$ & $44(27,3)$ & $37(22,98)$ & $30(18,63)$ \\
Jenis kelamin $\quad$ & & & \\
$\quad$ Laki-laki, (n) & 24 & 19 & 20 & 17 \\
$\quad$ Perempuan, (n) & 26 & 25 & 17 & 13 \\
Rerata usia, (tahun) & 5,76 & 6,00 & 5,28 & 6,04 \\
Rerata berat badan, kg (SB) & $18,9(7,60)$ & $20,7(10,05)$ & $17,9(9,70)$ & $21,43(13,54)$ \\
Status gizi (n) & & & & \\
$\quad$ Gizi kurang & 9 & 11 & 26 & 8 \\
$\quad$ Gizi baik & 40 & 27 & 11 & 18 \\
$\quad$ Overweight & 1 & 4 & 0 & 2 \\
$\quad$ Obesitas & 0 & 2 & 0 & 2 \\
Demam di rumah,(rerata hari) & 8,60 & 7,50 & 8,00 & 8,30 \\
Suhu tubuh saat MRS, (rerata $\left.{ }^{\circ} \mathrm{C}\right)$ & 37,94 & 37,92 & 37,95 & 37,95 \\
Riwayat berobat sebelumnya, $(\mathrm{n})$ & 21 & 12 & 21 & 11 \\
\hline
\end{tabular}

Tabel 2. Gejala klinis demam tifoid anak

\begin{tabular}{lcccc}
\hline $\begin{array}{c}\text { Gejala Klinis } \\
(\mathrm{n})\end{array}$ & $\begin{array}{c}\text { Kloramfenikol } \\
(\mathrm{n}=50)\end{array}$ & $\begin{array}{c}\text { Tiamfenikol } \\
(\mathrm{n}=44)\end{array}$ & $\begin{array}{c}\text { Sefiksim } \\
(\mathrm{n}=37)\end{array}$ & $\begin{array}{c}\text { Azitromisin } \\
(\mathrm{n}=30)\end{array}$ \\
\hline Anoreksia & 44 & 28 & 27 & 26 \\
Lidah kotor & 17 & 21 & 17 & 14 \\
Konstipasi & 17 & 15 & 15 & 12 \\
Kembung & 8 & 5 & 5 & 4 \\
Diare & 12 & 9 & 8 & 7 \\
Mual & 26 & 25 & 21 & 16 \\
Muntah & 25 & 22 & 22 & 13 \\
Nyeri perut & 18 & 18 & 11 & 13 \\
Batuk & 19 & 19 & 16 & 11 \\
Hepatomegali & 16 & 15 & 18 & 14 \\
\hline
\end{tabular}

Tabel 3. Karakteristik laboratorium subyek penelitian

\begin{tabular}{lcccc}
\hline Karakteristik & $\begin{array}{c}\text { Kloramfenikol } \\
(\mathrm{n}=50)\end{array}$ & $\begin{array}{c}\text { Tiamfenikol } \\
(\mathrm{n}=44)\end{array}$ & $\begin{array}{c}\text { Sefiksim } \\
(\mathrm{n}=37)\end{array}$ & $\begin{array}{c}\text { Azitromisin } \\
(\mathrm{n}=30)\end{array}$ \\
\hline $\mathrm{Hb}(\mathrm{g} / \mathrm{dl})$, rerata $(\mathrm{SB})$ & $11,87(1,48)$ & $12,03(1,20)$ & $11,70(1,20)$ & $11,75(1,39)$ \\
Leukosit $\left(\mathrm{mm}^{3}\right)$, rerata $(\mathrm{SB})$ & $8558(3754)$ & $7535(3191)$ & $8824(6331)$ & $7294(3450)$ \\
Trombosit $\left(\mathrm{mm}^{3}\right)$, rerata (SB) & $275.760(107.489)$ & $271.545(113.530)$ & $252.918(133.223)$ & $247.766(112.810)$ \\
Hematokrit $(\%),(\mathrm{SB})$ & $35,90(4,50)$ & $36,20(3,80)$ & $34,90(3,60)$ & $35,08(4,40)$ \\
\hline
\end{tabular}


Novie Homenta Rampengan: Penggunaan antibiotik terapi demam tifoid tanpa komplikasi

Tabel 4. Respons bebas demam berdasarkan jenis antibiotik

\begin{tabular}{lccccc}
\hline Kelompok & $\begin{array}{c}\text { Rerata waktu } \\
\text { bebas demam (jam) }\end{array}$ & SB & Min & Max & p \\
\hline Kloramfenikol & 40,30 & 28,30 & 6 & 120 & 0,35 \\
Tiamfenikol & 45,27 & 38,05 & 6 & 240 & \\
Sefiksim & 50,81 & 32,30 & 6 & 126 & \\
Azitromisin & 37,90 & 32,75 & 6 & 120 & \\
\hline
\end{tabular}

Tabel 5. Respons terapi antibiotik berdasarkan lama rawat

\begin{tabular}{lccccc}
\hline Kelompok & $\begin{array}{c}\text { Rerata } \\
\text { lama rawat (hari) }\end{array}$ & SD & Min & Max & p \\
\hline Kloramfenikol & 4,42 & 1,26 & 2 & 8 & 0,60 \\
Tiamfenikol & 4,75 & 1,73 & 3 & 13 & \\
Sefiksim & 4,81 & 1,63 & 2 & 9 & \\
Azitromisin & 4,56 & 1,27 & 3 & 7 & \\
\hline
\end{tabular}

azitromisin 4,56 (SB 1,27) hari, kelompok tiamfenikol yaitu 4,75 (SB 1,73) dan kelompok sefiksim 4,81 (SB 1,63). Hasil Anova dengan uji F menyatakan tidak terdapat perbedaan bermakna rerata lama rawat ke-4 jenis obat $(\mathrm{p}=0,600)$

\section{Pembahasan}

Penelitian kami memperlihatkan insidens demam tifoid yang hampir sama antara laki-laki dan perempuan (Tabel 1). Penelitian sebelumnya juga menyatakan bahwa angka kejadian demam tifoid tidak berbeda antara anak laki-laki dan perempuan. ${ }^{7}$ Usia terbanyak adalah di atas 5 tahun, sesuai dengan laporan Bhan dan Bhatnagar ${ }^{8}$ bahwa di daerah endemis kasus demam tifoid tersering pada usia 5-19 tahun, diikuti dengan usia 1-5 tahun. Pada usia 6-10 tahun merupakan masa anak mulai mengenal lingkungan dan bersosialisasi dengan temannya, mereka mulai mengkonsumsi makanan dan minuman yang tidak diketahui dengan jelas kebersihan. ${ }^{9}$ Cukup banyak pasien yang telah mendapatkan terapi antibiotik sebelum masuk rumah sakit. Hal tersebut berpengaruh terhadap lebih rendahnya waktu bebas demam yang ditemukan dibandingkan penelitian sebelumnya.

Gejala klinis demam tifoid sangat bervariasi, dari ringan sampai dengan berat sehingga memerlukan perawatan di rumah sakit. Variasi gejala tersebut disebabkan faktor galur Salmonella, status nutrisi, dan imunologik pejamu serta lama sakit dirumah. ${ }^{10}$
Gejala klinis demam tifoid juga dapat dipengaruhi oleh penyakit penyerta dan pemberian antibiotik sebelumnya. ${ }^{11}$ Gejala klinis terbanyak adalah anoreksia diikuti oleh mual, muntah, dan nyeri perut. Hasil pengamatan kami sesuai dengan Crump $\mathrm{dkk}^{12}$ yang menyatakan anoreksia ditemukan $85 \%$, mual maupun nyeri perut $50 \%$, dan batuk $35 \%$ pasien.

Rerata subyek memperlihatkan hasil laboratorium darah perifer normal. Berdasarkan kepustakaan, pada demam tifoid tidak selalu ditemukan leukopenia. Sering hitung leukosit dalam batas normal dan dapat pula leukositosis, terutama apabila disertai komplikasi lain. ${ }^{13}$

Respons terapi berbagai antibiotik dinilai dengan waktu bebas demam dan lama rawat di rumah sakit. Saat reda demam (time of fever defervescence) merupakan parameter keberhasilan pengobatan dan saat tersebut menentukan efektifitas antibiotik. ${ }^{14}$ Dalam penelitian tahun 1990-1994 di Bagian IKA FKUI RSCM, pasien demam tifoid anak yang diberi antibiotik kloramfenikol, ampisilin/amoksisilin, seftriakson, sefiksim dan kotrimoksasol, melihat saat demam turun berturut-turut 4,2; 5,2; 5,4; 5,7; dan 6,5 hari. Dengan demikian, pemantauan suhu pada hari ke-4 sampai hari ke-5 setelah pemberian antibiotik dapat digunakan sebagai titik evaluasi. Apabila suhu turun dan klinis anak membaik berarti terapi berhasil. Sedangkan apabila demam menetap mungkin terdapat infeksi lain, komplikasi, atau kuman penyebab adalah MDR S. typhi. ${ }^{15}$ Dalam penelitian kami, waktu bebas panas paling pendek dicapai pada pasien yang 
diberikan azitromisin, yaitu 37,90 (SB 32,75) jam, kemudian diikuti oleh kloramfenikol 40,30 (SB 28,3), tiamfenikol 45,27 (SB 38,05), dan sefiksim 50,81 (SB 32,3). Akan tetapi secara statistik tidak terdapat perbedaan pada keempat kelompok tersebut.

Rerata lama rawat hampir sama, berkisar antara 4-5 hari, lama rawat paling singkat ditemukan pada kelompok kloramfenikol, yaitu 4,42 (SB 1,26) hari, diikuti azitromisin 4,56 (SB 1,27), tiamfenikol 4,75 (SB 1,73), dan kelompok sefiksim 4,81 (SB 1,63), tidak terdapat perbedaan bermakna.

Kami medapatkan tidak terdapat perbedaan antara waktu bebas demam dan lama rawat di rumah sakit pada keempat kelompok antibiotik. Kloramfenikol dan tiamfenikol masih cukup sensitif untuk demam tifoid. Tiamfenikol adalah turunan kloramfenikol yang juga aktif terhadap spesies Salmonella dan dapat diberikan secara oral. Obat dapat diberikan dengan dosis lebih kecil, interval lebih lama, dengan angka kekambuhan, dan pengidap kuman (carrier) yang terjadi lebih sedikit. Walaupun dapat menyebabkan depresi sumsum tulang, tetapi hampir tidak pernah terjadi anemia aplastik. Pada pasien demam tifoid usia remaja dan dewasa didapatkan suhu kembali normal dalam waktu 3-5 hari dan lama pengobatan sekitar 7-14 hari. Dalam pengobatan demam tifoid pada anak tiamfenikol dapat dijadikan sebagai obat pilihan pertama menggantikan kloramfenikol, walaupun masih perlu penelitian lebih lanjut oleh karena belum dapat dilihat angka kekambuhan dan pengidap kuman setelah pengobatan. ${ }^{16}$

Pilihan obat antibiotik lini pertama pengobatan demam tifoid pada anak di negara berkembang didasarkan pada faktor efikasi, ketersediaan, dan biaya. Berdasarkan ketiga faktor tersebut, kloramfenikol masih menjadi obat pilihan pertama pengobatan demam tifoid pada anak.

Selama kurun waktu 4 tahun (2008-2012), jumlah kasus demam tifoid yang dirawat di RSCM Jakarta yang mendapat pengobatan kloramfenikol 13 orang, klinis membaik pada hari sakit ke- 6 yaitu 23,1\%. Berdasarkan pola kuman dan uji kepekaan terhadap antibiotik di RSCM pada tahun 2009-2010, hasil biakan S. typhi positif pada 8 spesimen, dengan sensitifitas kloramfenikol lebih dari $75 \% .^{17}$

Azitromisin adalah antibiotik golongan makrolid pertama yang termasuk dalam kelas azalide. Menurut WHO, pemberian azitromisin dengan dosis $10 \mathrm{mg} /$ $\mathrm{kgBB}$ selama 7 hari terbukti efektif pada terapi demam tifoid tanpa komplikasi pada anak dan dewasa dengan lama turun panas yang serupa dengan yang dilaporkan pada pemberian kloramfenikol. ${ }^{18}$ Penelitian invitro menunjukkan azitromisin lebih poten terhadap Salmonella spp. dibandingkan dengan obat lini pertama dan makrolid lain. Belum terdapat laporan tentang resistensi $S$. typhi terhadap azitromisin. Studi terbaru menunjukkan azitromisin efektif secara klinis dan bakteriologis dalam mengobati demam tifoid bahkan yang disebabkan oleh strain MDR. ${ }^{19}$

Azitromisin dan kloramfenikol berbeda dalam hal cara pemberian, farmakokinetik, prinsip terapi, dan efek samping. Azitromisin diberikan sekali sehari, sedangkan kloramfenikol diberikan empat kali sehari. Kedua antibiotik berpenetrasi ke dalam sel secara efektif, dan hal tersebut menerangkan aktivitas terapeutik obat terhadap patogen yang berada di intraselular seperti S. typhi. ${ }^{20}$

Sefiksim merupakan antibiotik golongan sefalosporin generasi ketiga oral, mempunyai aktifitas antimikroba terhadap kuman Gram positif maupun negatif termasuk Enterobacteriaceae. Sefiksim mempunyai efikasi dan toleransi yang baik untuk pengobatan demam tifoid anak. $^{21}$

Meskipun kloramfenikol sampai saat ini masih merupakan obat pilihan lini pertama (first drug of choice) untuk pengobatan demam tifoid pada anak, obat lini kedua seperti azitromisin dan sefiksim dapat dipertimbangkan dalam terapi demam tifoid tanpa komplikasi pada anak terutama pada kasus dengan kepatuhan (compliance) minum obat diragukan atau apabila kloramfenikol tidak dapat diberikan (misalnya jumlah leukosit $<2.000 /$ ul, adanya hipersensitif terhadap kloramfenikol, MDR S. typhi). ${ }^{20}$

Penelitian kami mempunyai beberapa keterbatasan. Kami tidak melakukan pemeriksaan biakan darah sebagai baku emas diagnosis demam tifoid serta tidak dapat memperlihatkan pola kuman dan kepekaan antibiotik secara invitro. Selain itu, karena penelitian retrospektif, kami tidak dapat melakukan kontrol dan penyeragaman terhadap lama rawat di rumah sakit pada tiap kelompok antibiotik. Lama rawat di rumah sakit tidak selalu berhubungan dengan derajat penyakit. Akan tetapi dapat berhubungan dengan variabel lain yang tidak berkaitan dengan penyakitnya, seperti adanya penyakit lain, anoreksia relatif, atau pasien yang tidak taat dalam minum obat. Dibutuhkan penelitian lanjutan dengan subjek yang lebih besar, pemeriksaan laboratorium mikrobiologi, 
serta dilakukan secara kohort prospektif untuk dapat mengevaluasi keberhasilan dan kegagalan terapi, perbaikan klinis maupun mikrobiologis, kejadian relaps secara klinis dan mikrobiologis, serta mengevaluasi berbagai faktor yang dapat mempengaruhi lama rawat. Sebagai kesimpulan, pemakaian antibiotik kloramfenikol, tiamfenikol, sefiksim, dan azitromisin pada penelitian kami menunjukkan tidak terdapat perbedaan dalam rerata waktu bebas demam, dan lama rawat inap.

\section{Daftar pustaka}

1. Crump JA, Luby SP, Mintz ED. The global burden of typhoid fever. Bull World Health Organ 2004;82:34653.

2. Nathin MA, Ringoringo P, Tambunan T. Antibiotic resistance pattern of paediatric typhoid fever patients at the departement of child health, Cipto Mangunkusumo, Jakarta in 1990-1994. Dalam: Nelman RHH, penyunting. Typhoid fever, profil, diagnosis and treatment in the 1990's. The first ISAC International Symposium. Sanur Bali;1990.h.194-205.

3. Azhali MS. Pengelolaan demam tifoid. Dalam: Naskah lengkap simposium Kongres Nasional Ilmu Kesehatan Anak X. KONIKA Bukit Tinggi;1996.h.75-84.

4. Bhutta ZA, Khan IA, Molla AM. Therapy of multidrug resistant typhoid fever with oral cefixime vs. intravenous ceftriaxone. Pediatr Infect Dis J 1994;13:990-4.

5. Girgis NI, Sultan Y, Hammad O, Farid ZH. Comparison of the efficacy, safety, and cost of cefixime, ceftriaxone, and aztreonam in the treatment of multidrug-resistant Salmonella typhi septicemia in children. Pediatr Infect Dis J 1995; 14:603-5.

6. Mirza SH. The prevalence and clinical features of multidrug resistant Salmonella typhi infections in Baluchistan, Pakistan. Ann of Trop Med and Parasitol 1995;89:513-9.

7. Rampengan TH. Demam Tifoid. Dalam: Rampengan $\mathrm{TH}$, penyunting. Penyakit infeksi tropik pada anak. Edisi ke-2. Jakarta: EGC; 2007.h.46-64.

8. Bahn MK, Bahl R, Bhatnagar S. typhoid and paratyphoid fever. Lancet 2005;366:749-62.

9. Adisasmito AW. Penggunaan antibiotik pada terapi demam tifoid anak di RSAB Harapan Kita. Sari Pediatri 2006;8:174-80.
10. Darmowandoyo W. Demam tifoid. Dalam: Sudarmo SSP, Garna H, Hadinegoro SRS, penyunting. Buku Ajar Ilmu Kesehatan Anak Infeksi \& Penyakit Tropis. Edisi Pertama. Jakarta: Balai Penerbit FKUI; 2002.h.367-75.

11. Bhutta ZA. Current concepts in the diagnosis and treatment of typhoid fever. BMJ 2006; 333:78-82.

12. Crump JA, Mintz ED. Global trends in typhoid and paratyphoid fever. Clin Infect Dis 2010;50:241-6.

13. Prasetyo RV, Ismoedijanto. Metode diagnostik demam tifoid pada anak. Divisi tropik dan penyakit infeksi bagian/SMF Ilmu Kesehatan Anak FK UNAIR/RSU Dr. Soetomo Surabaya. [diakses pada 5 Mei 2011]. Diunduh dari: http://www.pediatrik.com/buletin/06224114418-f53zji. doc

14. Hadinegoro SR. Strategi pengobatan demam tifoid pada anak. Dalam: Akib AAP, Tumbelaka AR, Matondang CS, penyunting. Naskah lengkap PKB Ilmu Kesehatan Anak XLIV. Pendekatan imunologis berbagai penyakit alergi dan infeksi. Jakarta:FKUI;2001.h. 105-16.

15. Tumbelaka AR. Tata laksana terkini demam tifoid pada anak. Simposium infeksi pediatri - tropik dan gawat darurat anak. Surabaya: Surabaya Intellectual Club; 2005.h.37-47.

16. Rismarini, Anwar Z, Merdjani A. Perbandingan efektifitas klinis antara kloramfenikol dan tiamfenikol dalam pengobatan demam tifoid pada anak. Sari Pediatri 2001;2:83-7.

17. Prayitno A. Pilihan terapi antibiotik untuk demam tifoid. Dalam: Naskah lengkap PKB Ilmu Kesehatan Anak LXIII. Update management of infectious diseases and gastrointestinal disorders. Jakarta: FKUI;2012.h.9-15.

18. World Health Organization. Diagnosis of typhoid fever. Dalam: Background document : the diagnosis, treatment and prevention of typhoid fever. Jenewa: WHO;2003.h.7-18.

19. Effa EE, Bukirwa H. Azitromisin for treating uncomplicated typhoid and paratyphoid fever (enteric fever). Cochrane Database Syst Rev 2008; 8:CD006083.

20. Butler T, Sridhar CB, Daga MK, Pathak K, Pandit RB, Khakhria R, dkk. Treatment of typhoid fever with azithromycin versus chloramphenicol in a randomized multicentre trial in India. J Antimicrob Chemother 1999;44:243-50.

21. Hadinegoro SRS, Tumbelaka AR, Satari HI. Pengobatan cefixime pada demam tifoid anak. Sari Pediatri 2001;4:182-7. 